\title{
Reservoir description and characterization of Eni field Offshore Niger Delta, southern Nigeria
}

\author{
Olawale Olakunle Osinowo ${ }^{1} \cdot$ Janet O. Ayorinde $^{2,3} \cdot$ Christiana Princess Nwankwo $^{4}$. \\ O. M. Ekeng ${ }^{5}$ - O. B. Taiwo ${ }^{5}$
}

Received: 18 February 2017/Accepted: 6 November 2017/Published online: 21 November 2017

(c) The Author(s) 2017. This article is an open access publication

\begin{abstract}
Integration of structural and horizon mapping of 3D seismic volume, petrophysical studies of over sixty (60) wireline logs, stratigraphic analyses, reservoir property modeling and production information have been adopted to study Eni field that has been experiencing production decline with increase in water output. Generated reservoir structural framework and spatial reservoir property distribution have proved useful to guide the optimal placement of proposed wells and also provide information needful for the development of best production plan that would guarantee effective oil drainage from the delineated reservoir compartments.
\end{abstract}

Keywords Reservoir compactments · Reservoir properties · Optimal well placement $\cdot$ Effective drainage $\cdot$ Niger delta

\section{Introduction}

As the energy demand of the world continues to grow due to improved standard of life associated with technological advancement and breakthroughs, so also are

Olawale Olakunle Osinowo

wale.osinowo@ui.edu.ng

1 Department of Geology, University of Ibadan, Ibadan, Nigeria

2 Life and Earth Sciences Institute, Pan African University, University of Ibadan Campus, Ibadan, Nigeria

3 Department of Geology and Mineral Sciences, University of Ilorin, Ilorin, Nigeria

4 Department of Petroleum Engineering, University of Ibadan, Ibadan, Nigeria

5 Chevron Nigeria Limited, Lekki, Nigeria the challenges associated with exploration and development of new fields, especially because most of the easy-to-find hydrocarbon reserves have already been discovered. As a result, oil exploration has gradually shifted to more challenging environments and thus the need to reduce exploration uncertainty and maximize recovery if supply is to keep up with demand. This need has therefore engendered a multidimensional approach to reservoir evaluation, which combines geophysics, geology, petrophysics, reservoir engineering and geostatistics for detailed evaluation of reservoir properties. Reservoir characterization is a technique involving quantitative distribution of reservoir properties, such as facies distribution, porosity, permeability, and fluids saturations (Journel 1995). This technique has gained significant relevance as well as attracted remarkable research effort since the first technical paper on twodimensional description of reservoir heterogeneity using regression analysis on well testing by Jahns (1966). The method has since evolved as a tool which integrates seismic derived information, well logs, pressure tests, cores and other engineering and geoscience data to provide adequate information required for reservoir modeling aimed at field development and reservoir management. This way maximum recovery is guaranteed with fewer wells in better positions and uncertainties in production forecast is reduced (Haldorsen and Damsleth 1993; Phillips 1996; Johnston 2004).

Several reservoir characterizing studies have been undertaking, especially to tackle production challenges associated with complex fields, usually presented with unpredictable stratigraphic and facies variation and oftentimes with related structural complexities. Example of such studies include the work of Jackson et al. (2005) who applied three-dimensional reservoir

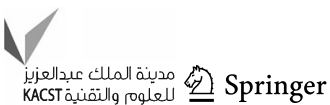


characterization and flow simulation techniques to address degrading recovery in a heterolithic tidal sandstone. Refae et al. (2008) also applied seismic and other relevant data to characterize the challenging Libya's Lehib field for the purpose of salvaging the field.

Eni Field located in approximately 40 feet water depth (Thakur et al. 1982) and situated about eight (8) miles offshore west Niger Delta in southern Nigeria (Fig. 1) occur in a relatively challenging environment where exploration uncertainty needs to be reduced for gainful exploration and exploitation of the hydrocarbon reserves. The field which consists of interstratified sandstones and shale units representing shore face to shelf deposition environment (Cook et al. 1999) has recently been experiencing decline in oil production, while water production on the other hand is on the increase. Material balance studies carried out on the reservoir as well as production decline curve plot which fits production data to the decline curve to estimate future production indicate undepleted reservoir. The decision to increase production for the purpose of maximizing recovery initiated the need to characterize the reservoir in order to be able to make informed decisions relating to placement of new wells for the purpose of optimizing reservoir activities and thus reduce water production.

\section{The geology of Niger Delta}

The Tertiary Niger Delta Basin located in southern Nigeria at the inland margin of the Gulf of Guinea is situated at the southernmost extremity of the elongated intra-continental Benue Trough. It is situated between latitudes $3^{\circ}$ and $6^{\circ} \mathrm{N}$ and longitudes $5^{\circ}$ and $8^{\circ} \mathrm{E}$ (Fig. 2). The basin is bounded by the Calabar Flank in the east, Benin Flank in the west, Gulf of Guinea in the south and in the north by older (Cretaceous) tectonic elements such as the Anambra Basin and Afikpo Syncline (Avbovbo 1978; Ejedawe et al. 1984; Tuttle et al. 1999). The evolution of the Niger Delta basin is controlled by pre- and syn- sedimentary tectonic activities described by Evamy et al. (1978), Ejedawe et al. (1984), Knox and Omatsola (1989) and Stacher (1995). The pre-sedimentary tectonic activities generated Cretaceous Fracture zones commonly expressed as trenches and ridges in the deep Atlantic. The fracture zones subdivide the West African Shield into individual basins, and in Nigeria, the fault zones form boundary faults that generated the Cretaceous Benue-Abakaliki Trough which is a failed arm of a rift triple junction associated with the opening of the south Atlantic (Lehner and De Ruiter 1977). Syn-sedimentary tectonic activities shaped the internal geometry of the basin and include gravity tectonics which became
Fig. 1 Location map of the study area Offshore Niger Delta

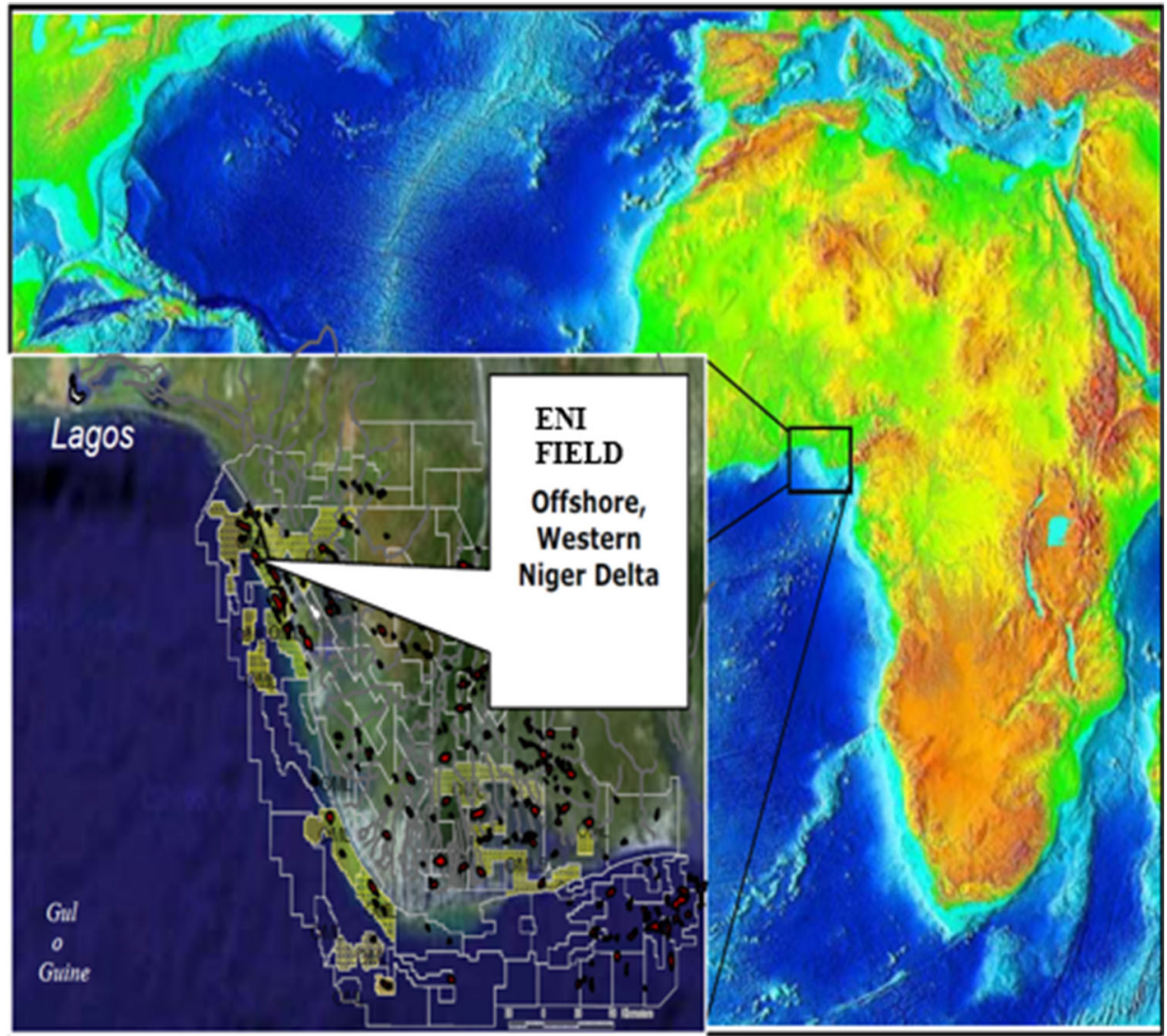


Fig. 2 Tectonic setting and structural elements of the Niger Delta Basin (Kogbe 1989)

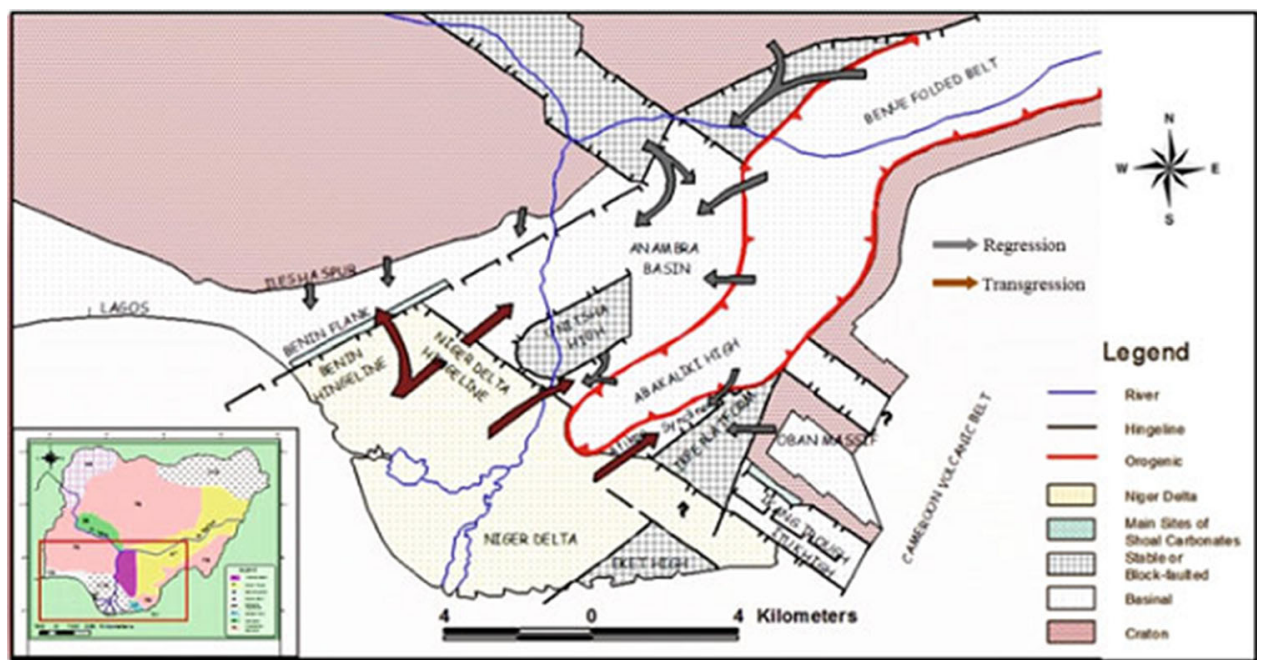

Fig. 3 a The Niger Delta complex and b Section through the continental shelf, slope and rise showing Structural domains of Niger Delta (Cohen and McClay 1996)
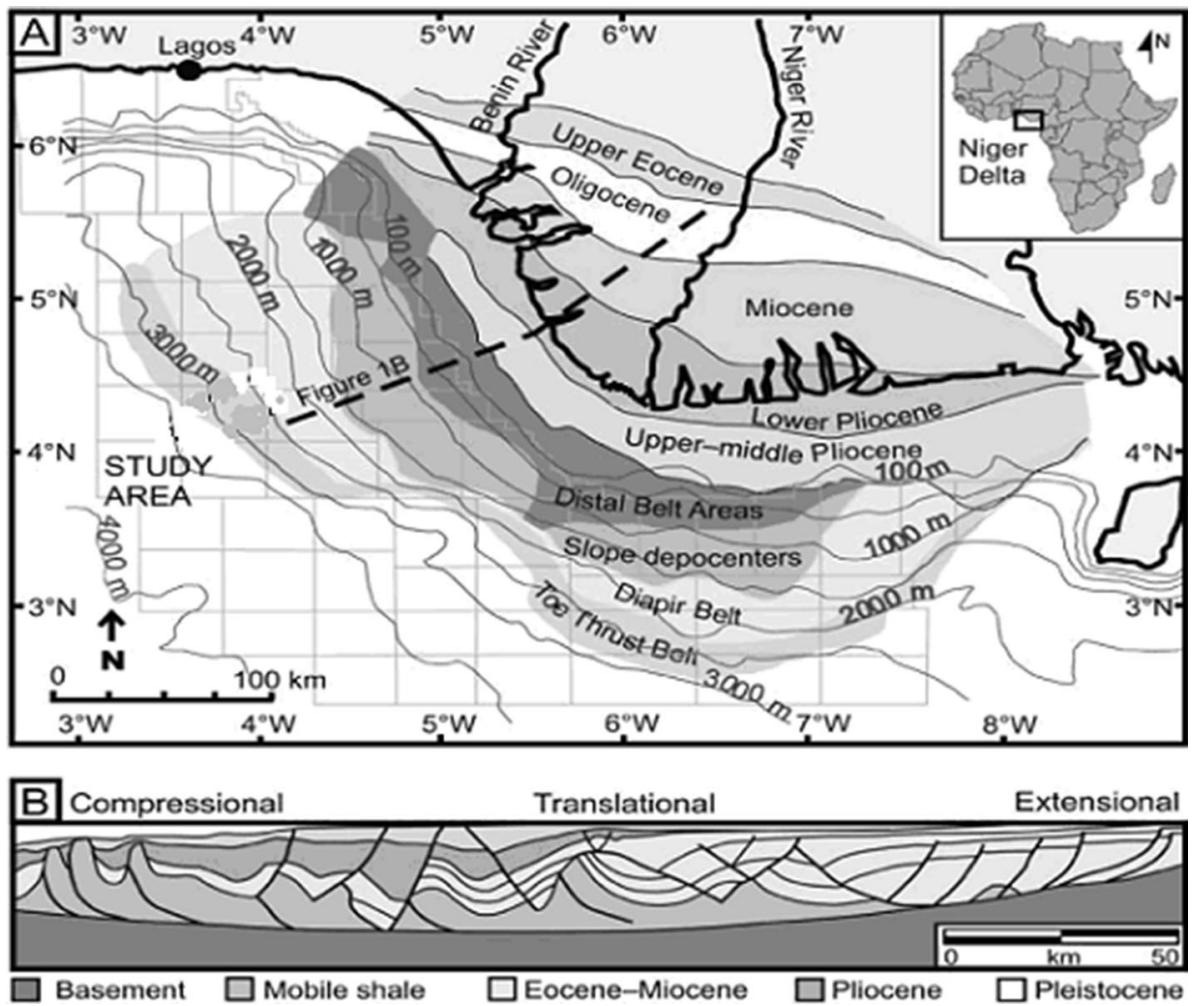

active after the rifting episode. The gravity tectonic event is expressed in complex sedimentary structures in the form synthetic and antithetic growth fault, roll-over anticlines and salt diapirs among others (Fig. 3).

The Niger Delta basin has area coverage of about $75,000 \mathrm{~km}^{2}$ and consists of an overall regressive clastic sequence which reaches a maximum thickness of about $12,000 \mathrm{~m}$ in the central part of the basin where there is maximum subsidence (Merki 1972). The basin consists of progradational, paralic sequences of Akata, Agbada and Benin Formations which builds southwards into the deep waters and this account for the Delta Complex in the Oligocene-Miocene times (Doust and Omatsola 1990). The structural framework of the basin as controlled by basin geometry, rate of sedimentation and the progradation of sandy deposits over under-compacted delta marine shale is dominated by many syn-depositional structural signatures associated with gravity tectonics.

The Eni field reservoirs are located in NW-SE trending Miocene depocenters, situated in a wave-dominated Niger Delta depositional system. The reservoir units occur as part of the Agbada Formation and comprises of stacked shallow 
marine fluvial-deltaic sediments separated by major marine shale units (Poston et al. 1981). The sands were deposited in middle to upper shore face, wave-influenced environments. The underlying Eocene-Oligocene Akata marine shales are the likely sources of the hydrocarbons to the reservoirs.

\section{Materials and methods}

This study integrated 3D seismic reflection and wireline $\log$ data with other supporting information such as checkshot survey data, formation well tops, formation cores, well test data as well as production history data to quantitatively determine the spatial variability of some important reservoir properties. Well logs which record different physical borehole parameters against depth were interpreted and subjected to various petrophysical analyses and also employed to carry out litho-stratigraphic correlation across the wells in order to establish the distribution and behavior of the lithological units of interest across different well locations. Various measured log parameters such as gamma radiation, natural spontaneous electrical potential, resistivity, density, neutron, sonic among others were employed to identify porous and permeable litho-units which are saturated with hydrocarbon and possess right qualities that distinct them as hydrocarbon reservoirs. In addition, other derivative reservoir parameters such as, reservoir thickness, Net-To-Gross (NTG), volume of shale $\left(\mathrm{V}_{\mathrm{sh}}\right)$ in the clastic reservoirs, effective porosity $\left(\varnothing_{\mathrm{eff}}\right)$, hydrocarbon saturation $\left(1-S_{w}\right)$ and facies distribution were derived from the well-log data to estimate the hydrocarbon potential of Eni field.

The 3D seismic reflection data comprising of in-lines and cross-line seismic sections were also carefully analyzed in terms of horizon mapping, structural interpretation and attribute extraction and analyzed to generate horizon surfaces, structural frameworks, depth structural maps as well as define the areal extents and invariably the Gross Rock Volume (GRV) of the identified reservoir units. Structural mapping involved identifying discontinuous and abruptly terminated reflection events which usually continue across the fault planes either thrown upward or downward depending on the nature of fault, whether normal or reverse dip slip fault. Horizon mapping of hydrocarbon saturated formations, identified to be hydrocarbon bearing from well-log signatures were carried out. Posting of hydrocarbon saturated formation tops on the seismic record through seismic to-well-tie with the aid of generated synthetic seismogram enabled the ease of mapping of horizons of interest.(Herrera and Van der Baan 2012). Horizon mapping involved carefully tracing the continuity of the target horizons across the different in- and cross-line sections at every 10th in and cross-line seismic record using the 3D auto track tool provided by Petrel interpretation software. Three horizons were carefully traced in total with each looped across the in- and cross-lines to generate horizon surface maps which indicate the spatial distribution of the formation within the subsurface, measured in seismic time (2-way time). Time structure maps were generated from the derived horizon surface maps by inserting the fault polygons of delineated major faults and subsequently converted to depth structure map using the layer cake velocity model with the aid of sonic calibrated check-shot data (Marsden 1989). The resultant depth structure map was used to generate the gross volume of the reservoir rock (GRV).

Different derived reservoir parameters were finally employed to model reservoir properties across the generated horizon surfaces. Property modeling involves distributing the generated reservoir parameters across the entire reservoir's 3D grid using well points as controls. Porosity model was generated using Gaussian random function simulation while the sequential indicator simulation was applied for the facies modeling.

Finally, core-derived information such as reservoir thickness, effective porosity, permeability, formation fluid properties among others was also extracted. The pressure, temperature and volume (PVT) as well as production history data were also analyzed to extract information such initial reservoir pressure and temperature, fluid's API gravity and Gas Oil Ratio (GOR) which were used to determine formation volume factor using the relation expressed in Eq. (1).

$B_{\mathrm{o}}=0.972+1.47 \times 10^{-4}\left(R_{\mathrm{s}}\left(\frac{\gamma_{\mathrm{s}}}{\gamma_{\mathrm{o}}}\right)^{0.5}+1.25 \times T\right)^{1.175}$

where $B_{\mathrm{o}}$ oil formation volume factor, $R_{\mathrm{S}}$ gas oil ratio, $T$ temperature, $\gamma_{\mathrm{g}}$ gas gravity and $\gamma_{\mathrm{o}}$ oil gravity.

\section{Volumetric analyses}

Volumetric analyses were carried out using the STOOIP volume equation (Eq. 2) to determine the quantity of hydrocarbon in the reservoir and compared with already produced volume with the aim of estimating unproduced hydrocarbon volume. The STOOIP equation uses the various derived parameters such as GRV (thickness of rock unit above the hydrocarbon - water contact (OWC), NTG, effective porosity $\left(\varnothing_{\text {eff }}\right)$, hydrocarbon saturation $\left(1-S_{w}\right)$ as well as the Formation Volume Factor (FVF), which estimates the change in hydrocarbon volume in the form of expansion/shrinkage between the reservoir in the 
subsurface and the storage tank on the surface, to calculate the volume of hydrocarbon in the reservoir.

$\mathrm{STOOIP}=\frac{\mathrm{GRV} * \mathrm{NTG} * \varnothing \mathrm{eff} *(1-\mathrm{Sw})}{\mathrm{FVF}}$

Deterministic and probabilistic (stochastic) approaches were adopted to determine the hydrocarbon volumes in the various delineated reservoir sands (Demirmen 2007). The probabilistic approach varied some reservoir parameters such as the thickness of the reservoir by varying the fluid contacts; it also varied NTG, porosity as well as and water saturation $\left(\mathrm{S}_{\mathrm{w}}\right)$. The probabilities of getting 90,50 and $10 \%$ of volume in place were expressed as P10, P50 and P90, respectively (Samimi and Karimi 2014). The deterministic approach on the other hand considered two (2) different scenarios. The first (scenario 1) estimated the oil initially in place within the generated 3D grid using core-derived reservoir parameters such as porosity, $\mathrm{S}_{\mathrm{w}}$ and NTG combined with the initial formation volume factor that was calculated from well test data. The second scenario (scenario 2 ) on the other hand calculated oil volume using average petrophysical parameters such as porosity, NTG and $S_{\mathrm{w}}$ derived from well $\operatorname{logs}$, also using the initial oil formation volume factor (Samimi and Karimi 2014). Figure 4 presents the workflow which summarizes the different activity steps embarked upon to characterize Eni field, Niger Delta, southern Nigeria.

\section{Results and interpretation}

This section presents the different results obtained from petrophysical, facies analyses, seismic interpretation, and volumetric analyses carried out to characterize the reservoir sands mapped for hydrocarbon potential evaluation of Eni field in offshore west Niger Delta, southern Nigeria. Interpreted and analyzed well-log signatures delineated three (3) sand units H10, G20 and E40. The three sand bodies were selected based on their hydrocarbon saturation, thickness, effective porosity and other positive petrophysical properties that distinct them as favorable hydrocarbon reservoirs. The delineated sand units were correlated across five (5) well locations in Eni field based on available well$\log$ data. Litho-stratigraphic correlations show the distribution of the reservoir sand units in pictorial form across

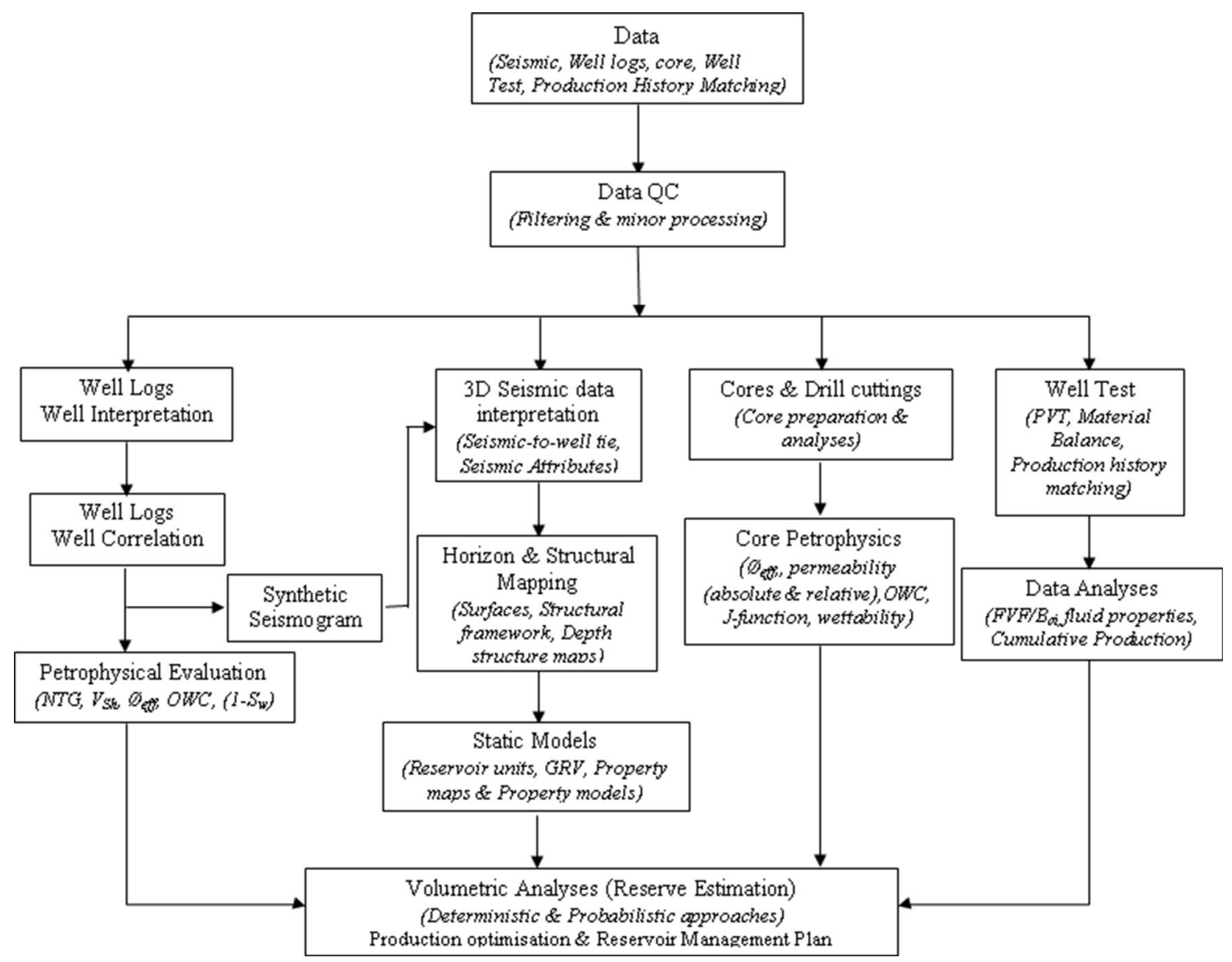

Fig. 4 Workflow adopted to characterize Eni field, southern Nigeria 


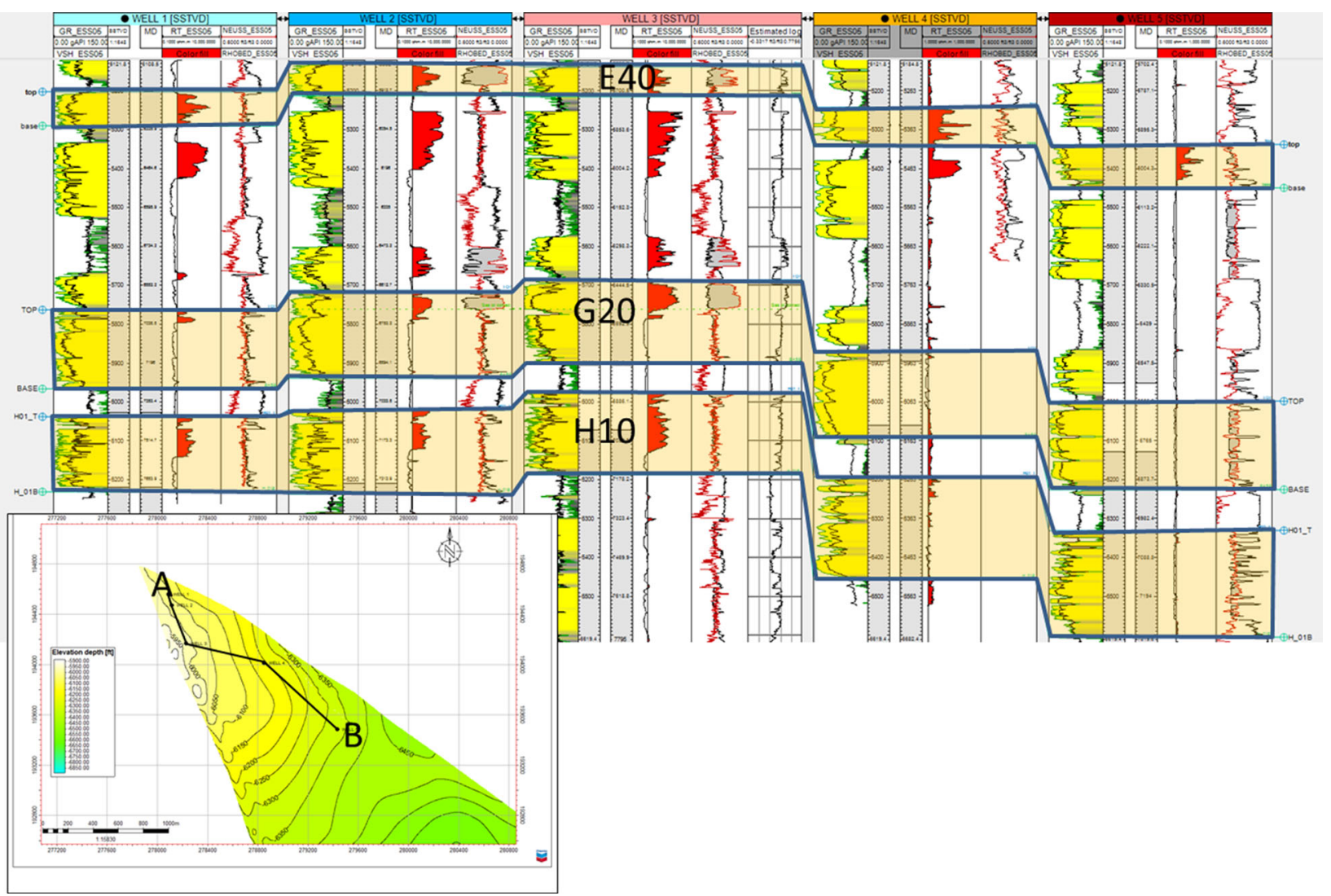

Fig. 5 Structural cross section through targeted sands (H, G, and E)

the correlated well locations and are presented in Fig. 5, for all the sand units H10, G20 and E40. Figures 6, 7 and 8 present the correlated panel of the individual sand units across the correlated wells. Gamma ray, derived $\mathrm{V}_{\mathrm{sh}}$ and resistivity logs were combined together to trace similarities of $\log$ responses for sand bodies encountered in wells A, B and $\mathrm{C}$ as indicated in the insert map (Fig. 5).

The delineated reservoir sands exhibit very strong degree of correlation and similarity in structures and thickness distribution. Generally, the sands were observed to thicken basinward, which is a typical thickening pattern in the Niger Delta Basin and characteristic of transition environment, here, transition from paralic Agbada to continental Benin Formation (Amigun and Bakare 2013). It was also observed that shale layers increased in thickness with depth, while the sand bodies decreases in thickness with depth. Facies analysis indicate that sand gross thickness varies from 190 to $280 \mathrm{ft}$., 201-239 ft. and 71-109 ft., for horizons H10, G20 and E40 respectively (Table 1), while the hydrocarbon saturated sand thicknesses, representing productive thickness of reservoir sands H10, G20 and E40 ranges from 180 to $265 \mathrm{ft}, 189-230 \mathrm{ft}$. and 65-98 ft., respectively (Table 1). The lateral distribution of sand bodies in terms of thickness and depth of occurrence as correlated across the five (5) penetrated wells (Fig. 5) indicate an anticlinal structure with the crest of the anticline coinciding with well location three (3), while wells 4 and 5 penetrated the up-dip and down-dip limbs of the anticline, respectively.

The summary of generated petrophysical information derived from well-log analyses is presented in Table 1.

Generally, the mapped reservoir sand units are reasonably thick with good lateral continuity across each section of the field. A careful study of the different stratigraphic units as shown by the gamma ray log motif indicates stacked sand and shale sequences which suggest fluvialdeltaic to barrier bar and open marine depositional environment (Snedden 1987; Rider 1986). Reservoir sand G20 displayed characteristic serrated cylindrical bell-shaped gamma ray log motif (Fig. 6) with high sand content (stacked sand and shale sequences), evident as very high NTG value (average). Combination of these facts suggests that the reservoir units are dominantly middle-upper shoreface and tidal channel sands (Omoboriowo et al. 2012).

Figure 8 indicates a thickly bedded sand unit (E40) which shows a coarsening upward sequence with little nonsand interval as indicated by the log motif. This unique 


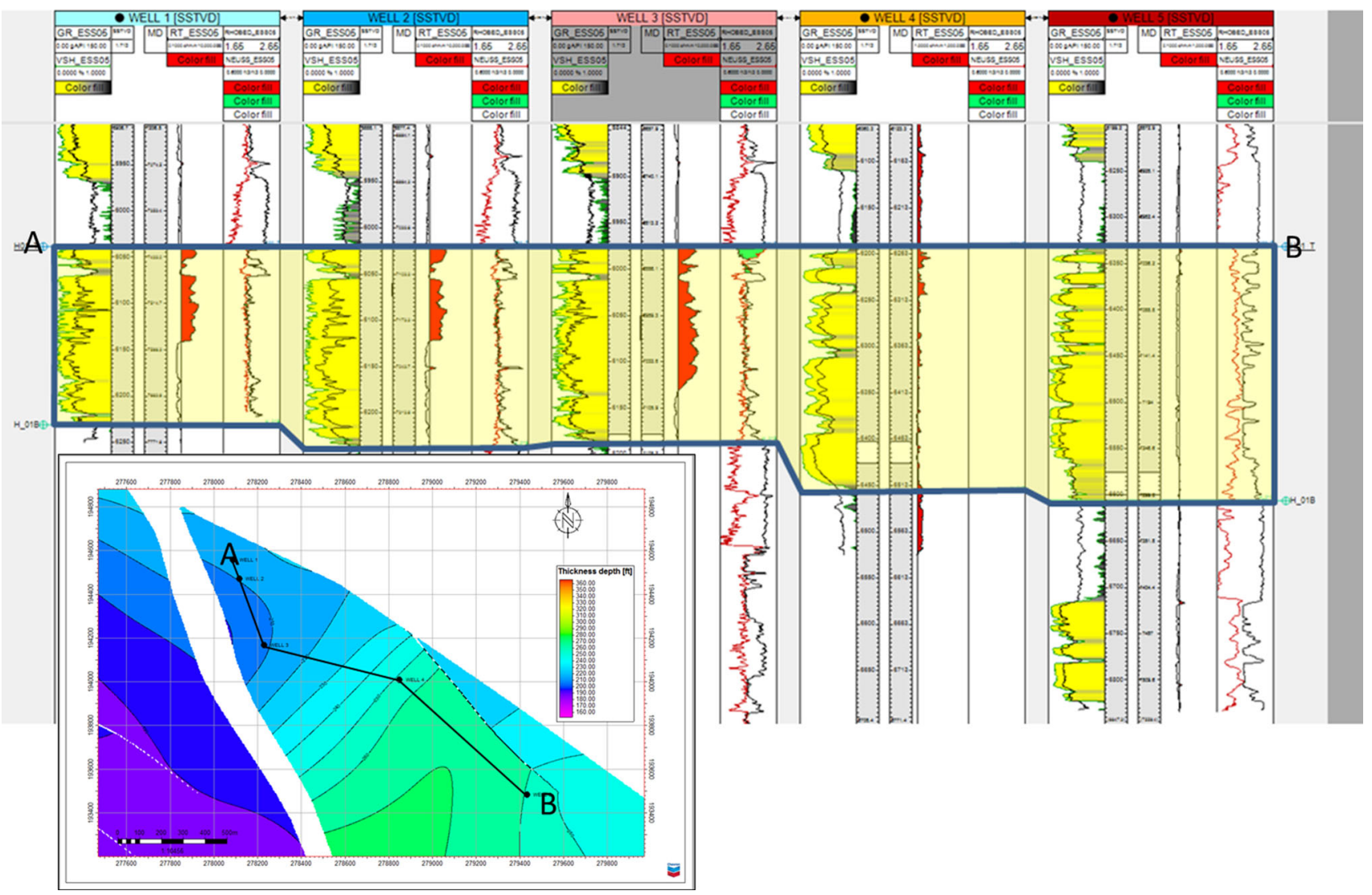

Fig. 6 Stratigraphic cross section of reservoir sand H10

pattern is characteristic of tidal channel sand deposited in a deltaic environment (Dalrymple and Choi 2007). The tidal channel sands are observed to prograde into barrier bar sand identified in wells $1-3$.

Seismic data interpretation generated horizon surfaces and structural framework of the delineated reservoirs. Structural mapping delineated a total of 55 normal and reverse (antithetic and synthetic) faults from the seismic sections (Fig. 9) which were identified as discontinuity and abrupt termination of coherent seismic reflection events with the aid of semblance seismic attributes (Brown 1986). Eight (8) of the mapped structures were considered to be major because of their relative regional extent, while the remaining faults were classified as minor discontinuities. Horizon mapping of identified hydrocarbon saturated sand units from the well logs posted on the 3D seismic sections generated three (3) different horizon surfaces from the seismic volume. The resultant surfaces also generated three depth structure maps after incorporating the structural elements. The generated depth structure maps from the three mapped horizons are presented in Figs. 10, 11 and 12. The maps show distribution of the reservoir sand units in terms of thickness, topography and relief as dictated by the structures. Two main types of structures are prominent in the reservoir as shown in the generated depth structure maps. Very prominent is the fault system, four (4) of them, which divide the entire field into four (4) structural blocks, designated as A, B, C and D (Fig. 10). The second prominent structure that characterizes the field is anticlines, three (3) in total. Two of the anticlines, located in the central and southeastern parts of the study area, are intercepted by faults, while the third anticlinal structure mapped in the northwestern part of the field is not fault-assisted; it is a four (4)-way dip anticline closure. The two fault-assisted anticlines show two-way dip anticline closures. In this type of structural traps, a combination of anticline and fault system framework restrained hydrocarbon movement and trapped oil and gas into the identified hydrocarbon pools (Gay 1999; Reijers 1996; Reijers 2011). The estimated areal extent in the block $\mathrm{C}$ sands located in the southeastern part of the field identified as sand tops H10, G20 and E40 are approximately 87.4, 75.4 and 558.7 acres, respectively.

\section{Reservoir property maps}

Different formation evaluation parameters determined from petrophysical analyses such as porosity and water 


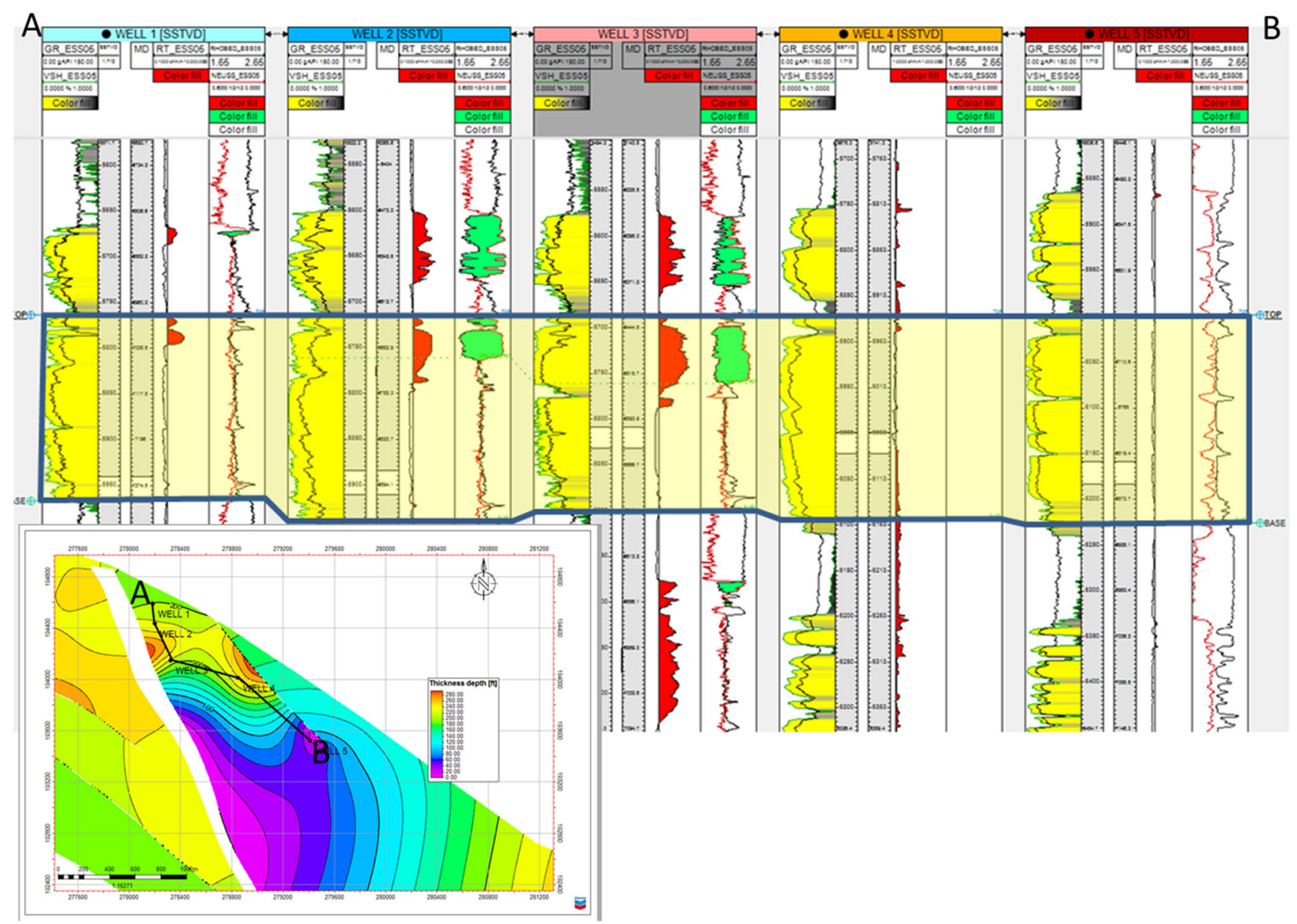

Fig. 7 Stratigraphic cross section of reservoir sand G20

saturation were employed to generate property maps for the identified three reservoir units. This enabled the prediction of reservoir properties beyond well locations across the whole reservoir (Behrenbruch et al. 1985; Norrena and Deutsch 2002). A combined assessment of different property maps is a useful tool credible for providing information about parts of the reservoir with excellent qualities, especially useful for decision making regarding selection of points for new/additional well(s) within the reservoir (Guyaguler 2002; Farshi 2008).

Accurate porosity information is required for characterizing a reservoir, especially due to its role in evaluating the volume of hydrocarbon stored in the pore spaces located within sand grains (Schmidt and McDonald 1980). Porosity distribution value across the reservoir sand $\mathrm{H} 10$ ranges from 0.25 to 0.32 , while the value ranges from 0.28 to 0.32 and 0.29 to 0.34 in G20 and E40 sands, respectively (Figs. 13, 14 and 15).

The water saturation maps generated across the mapped reservoir sands which indicate the ratio of the hydrocarbon in the reservoir pore volume are presented in Figs. 16, 17 and 18 for sands H10, G20 and E40, respectively. Water saturation in reservoir sand $\mathrm{H} 10$ ranges from 0.2 to 0.65 (Fig. 16), while the saturation property maps for reservoir sand G20 and E40 show range from 0.15 to 0.65 and 0.2 to 0.65 , respectively (Figs. 17, 18). However, the block C section of the reservoir sands in horizons H10, G20 and E40 has slightly lower water saturation value than the average water saturation range of the entire field; here water saturation ranges from 0.2 to $0.37,0.15$ to 0.25 and 0.2 to 0.37 , respectively.

Analyses of core data indicate average porosity value between 0.238 and 0.241 , while water saturation ranges between 0.127 and 0.13 . Additional information generated for the purpose of characterizing the delineated reservoirs through the evaluation of PVT and other production data include initial reservoir pressure which ranges from 2328 to 2553 psia and average reservoir temperature (170 to 180 F). The average American Petroleum Institute (API) gravity for encountered formation fluids ranges from 20.5 to 34.2, while the initial GOR ranges from 350 to 396 and oil and gas viscosities were determined to range from 0.57 cp to $2.57 \mathrm{cp}$ and $0.65 \mathrm{cp}$ to $0.67 \mathrm{cp}$, respectively. The generated information from the core, PVT and production 


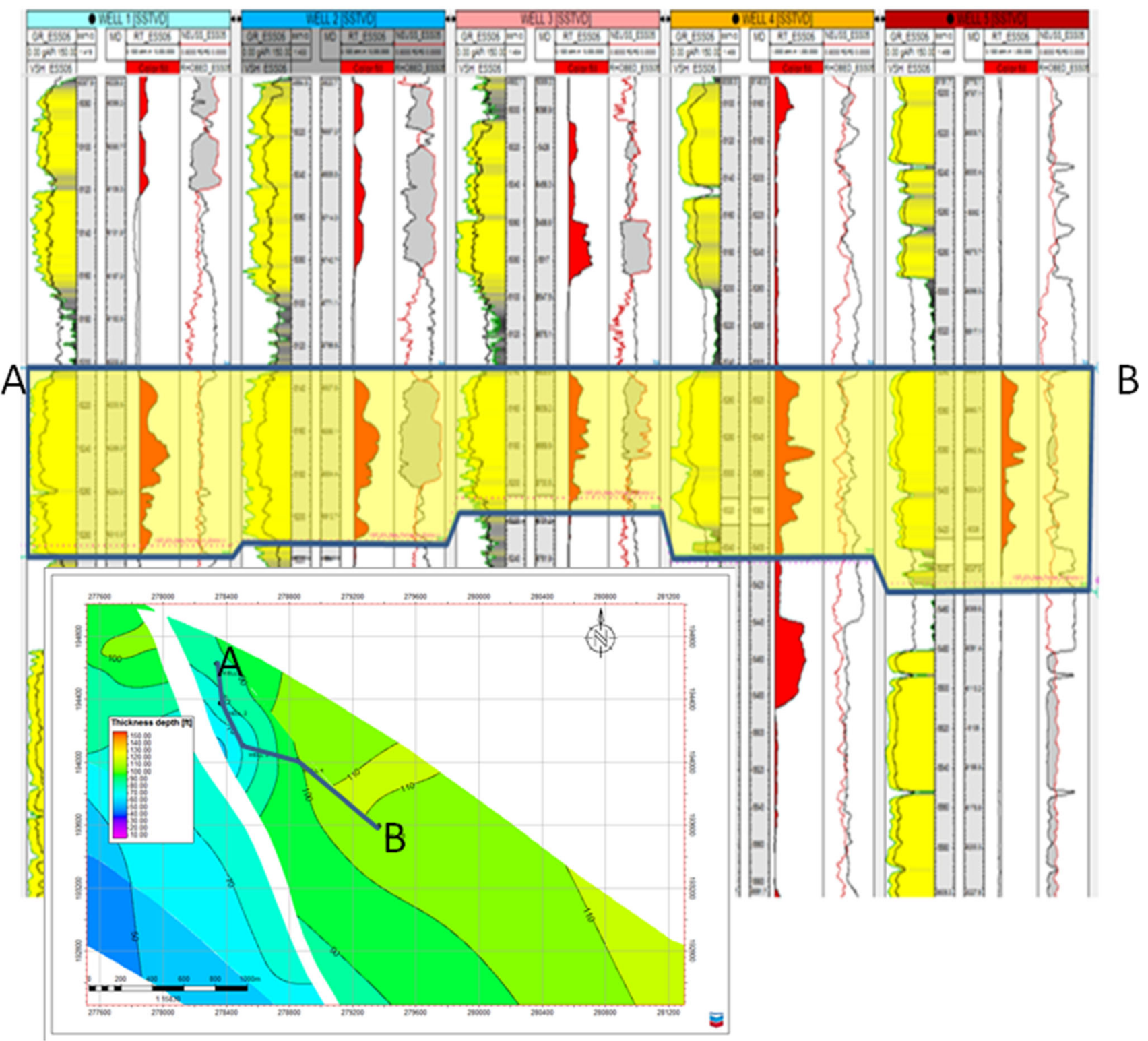

Fig. 8 Stratigraphic cross section of reservoir sand E40

Table 1 Reservoir properties range and average values

\begin{tabular}{|c|c|c|c|c|c|c|}
\hline \multirow[t]{2}{*}{ Reservoir } & \multicolumn{2}{|l|}{$\mathrm{H} 10$} & \multicolumn{2}{|l|}{ G20 } & \multicolumn{2}{|l|}{ E40 } \\
\hline & Range & Mean & Range & Mean & Range & Mean \\
\hline Gross thickness (ft) & $208-280$ & 228 & $22-239$ & 180 & $71-109$ & 88 \\
\hline NTG & $0.86-0.96$ & 0.91 & $0.91-0.96$ & 0.93 & $0.81-0.97$ & 0.91 \\
\hline Porosity & $0.28-0.33$ & 0.31 & $0.32-0.35$ & 0.34 & $0.30-0.35$ & 0.33 \\
\hline Sw & $0.2-0.305$ & 0.25 & $0.15-0.25$ & 0.20 & $0.18-0.4$ & 0.27 \\
\hline
\end{tabular}

information served as input in Eq. 1 to calculate the formation volume factor $\left(\mathrm{B}_{\mathrm{oi}}\right)$ which ranges in value from $1.209 \mathrm{Rb} / \mathrm{Stb}$ to $1.33 \mathrm{Rb} / \mathrm{Stb}$ across the delineated reservoirs.

\section{Estimation of hydrocarbon volumes}

The result of volumetric analyses carried out on reservoir sand $\mathrm{H} 10$ using probabilistic approach is presented in 
Fig. 9 Seismic section of the study area with some picked faults

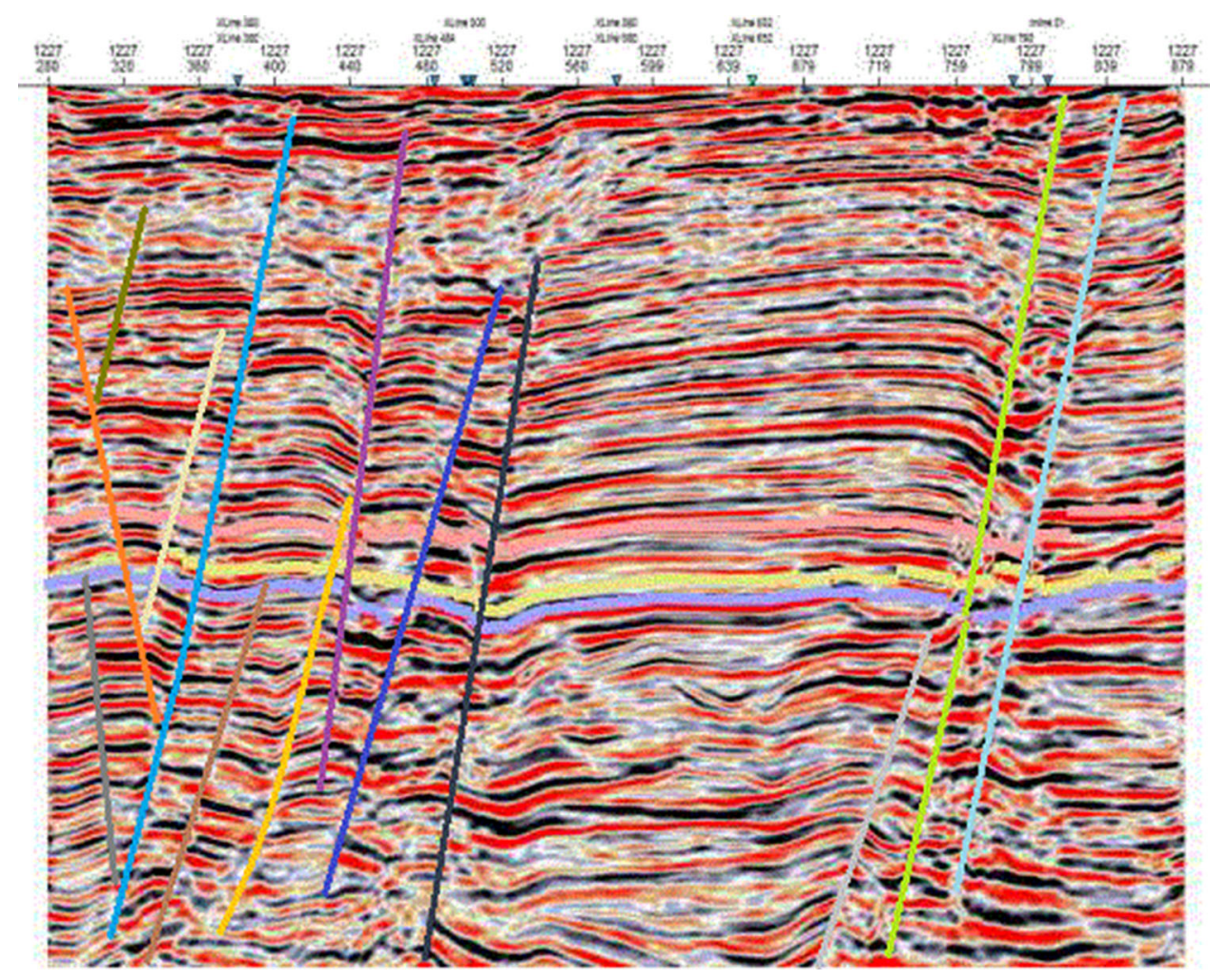

Table 2. The table shows the P10, P50 and P90, which indicate 90,50 and $10 \%$ probabilities of getting the volume of fluids in place as 13.97 MMSTB, 11.69 MMSTB and 10.91 MMSTB, respectively. Also the obtained hydrocarbon estimates in reservoir sand G20 for P10, P50 and P90, respectively, are 3.63 MMSTB, 3.18 MMSTB and 2.92 MMSTB, respectively. Volumetric analysis carried out on reservoir sand E40 generated P10 to be 49.7 MMSTB, P50 to be 41.7 MMSTB and P90 value of 39.5 MMSTB, respectively.

The deterministic approach generated two (2) sets of results for scenarios 1 and 2 . Table 3 presents the summary of the volumetric analyses using the deterministic approach and the average of the two scenarios gave STOOIP volumes of 11.96 MMSTB, 3.12 MMSTB and 43.64 MMSTB for reservoir sands H10, G20 and E40, respectively.

\section{Discussion of results}

The analyses, interpretation and synthesis of various information derived from well logs, 3D seismic, core data as well as well test and production history data have aided the delineation of three (3) lithologic units with favorable petrophysical properties which were classified as hydrocarbon saturated clastic reservoirs. The delineated reservoir units presented characteristic serrated cylindrical and coarsening upward log motif signatures which indicate the reservoir sands to consist mainly of stacked sands and shale sequences. The definitive log signatures and lithologic distribution suggest fluvial-deltaic to barrier bar, middleupper shoreface and tidal channel sands to open marine environments which suggest both vertical and lateral heterogeneous reservoir rocks across the Eni field. The 3D seismic horizon mapping, especially as enhanced through reservoir property mapping, indicates the spatial distribution and variability of different petrophysical properties across each of the identified reservoir units. This implies heterogeneity which could result in some sections of the reservoir having slightly different reservoir properties than other.

The structural framework as generated from the 3D seismic volume indicates a four (4)-way dip closure and two (2) fault-assisted anticlines as the dominant trapping mechanism that confined hydrocarbon fluids to the different reservoir units. The faulting systems as determined by the structural mapping divided each reservoir horizons into three (3) different blocks which were indicated by well test data to be isolated and non-communicating (Bailey et al. 2002; Sweet and Sumpter 2007). The production and management of these series of heterogeneous and compartmentalized reservoirs units may be slightly challenging. Oftentimes, the goal of the production team is usually to maximize production through fewer numbers of wells. However, managing this type of field requires adequate information, such that would be generated through 
Fig. 10 Depth structure map of sand top H10

Fig. 11 Depth structure map of sand top G20
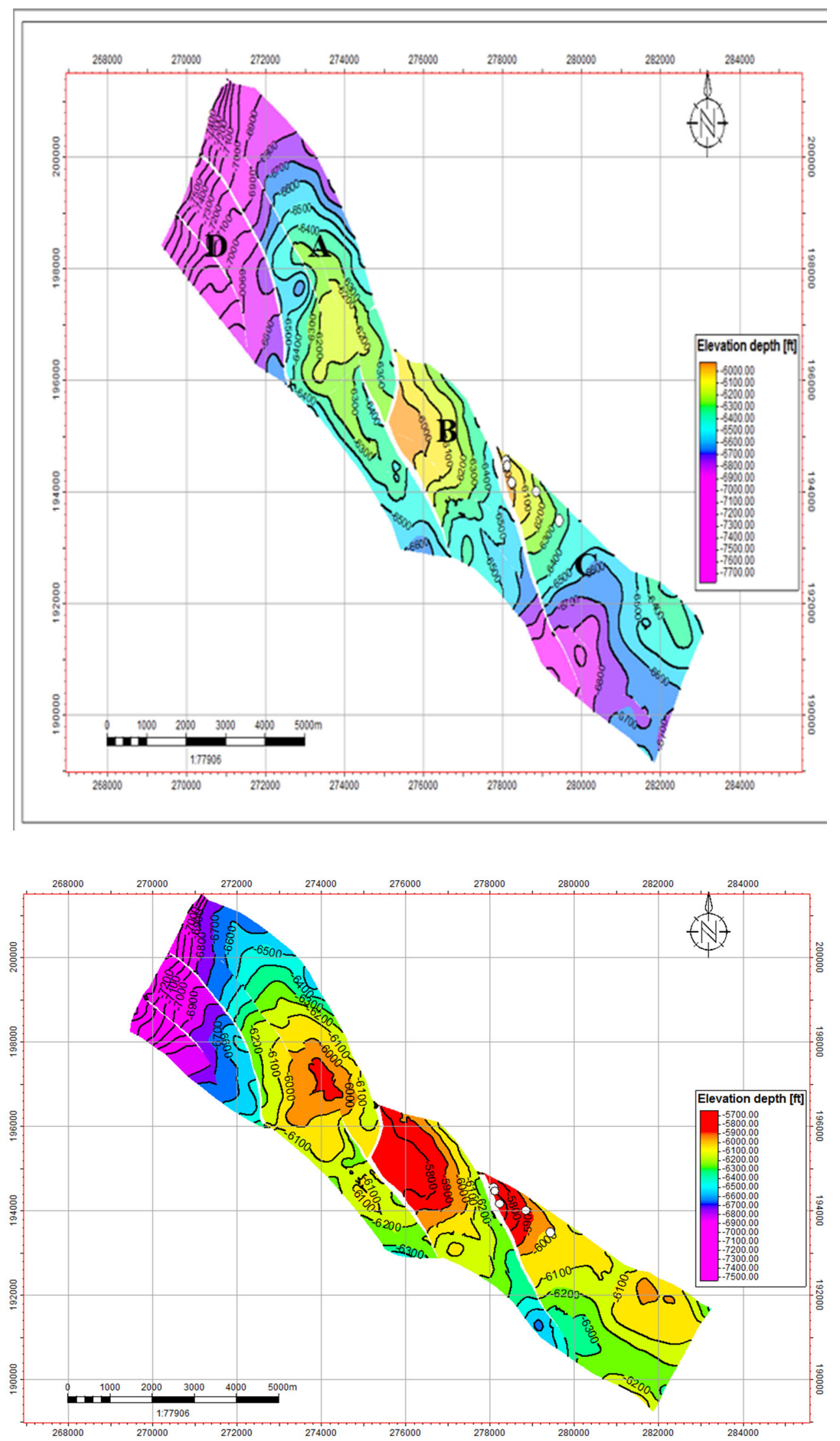

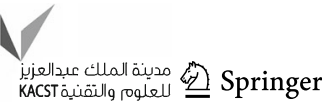


Fig. 12 Depth structure map of sand top E40
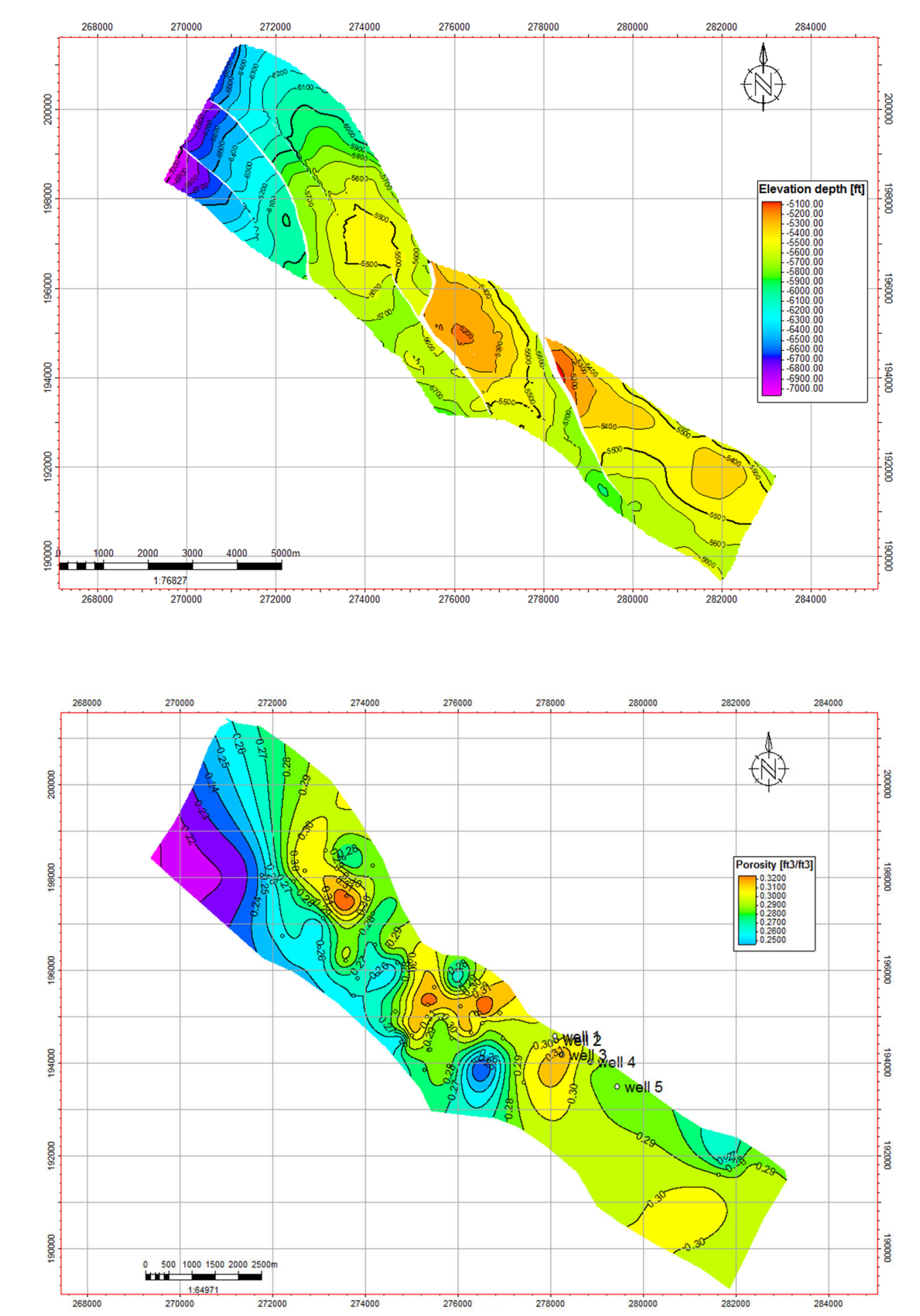

Fig. 13 Porosity map of sand H10

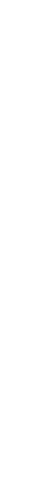

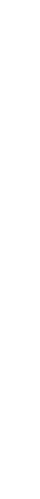

integrated studies aimed at characterizing the field (Smalley and Muggeridge 2010). The main reason for reduction in oil production and increase in water output challenges confronting Eni field despite un-depleted reserves could result when trying to manage such a challenging field with limited/inadequate information. A clear case of increase in water production could result when trying to sweep oil into production wells using water injection technique across isolated and non-communicating reservoir units. Eni field and indeed such with similar isolated reservoir compartments has to be managed carefully and individually. The placement of the wells, 
Fig. 14 Porosity map of sand G20
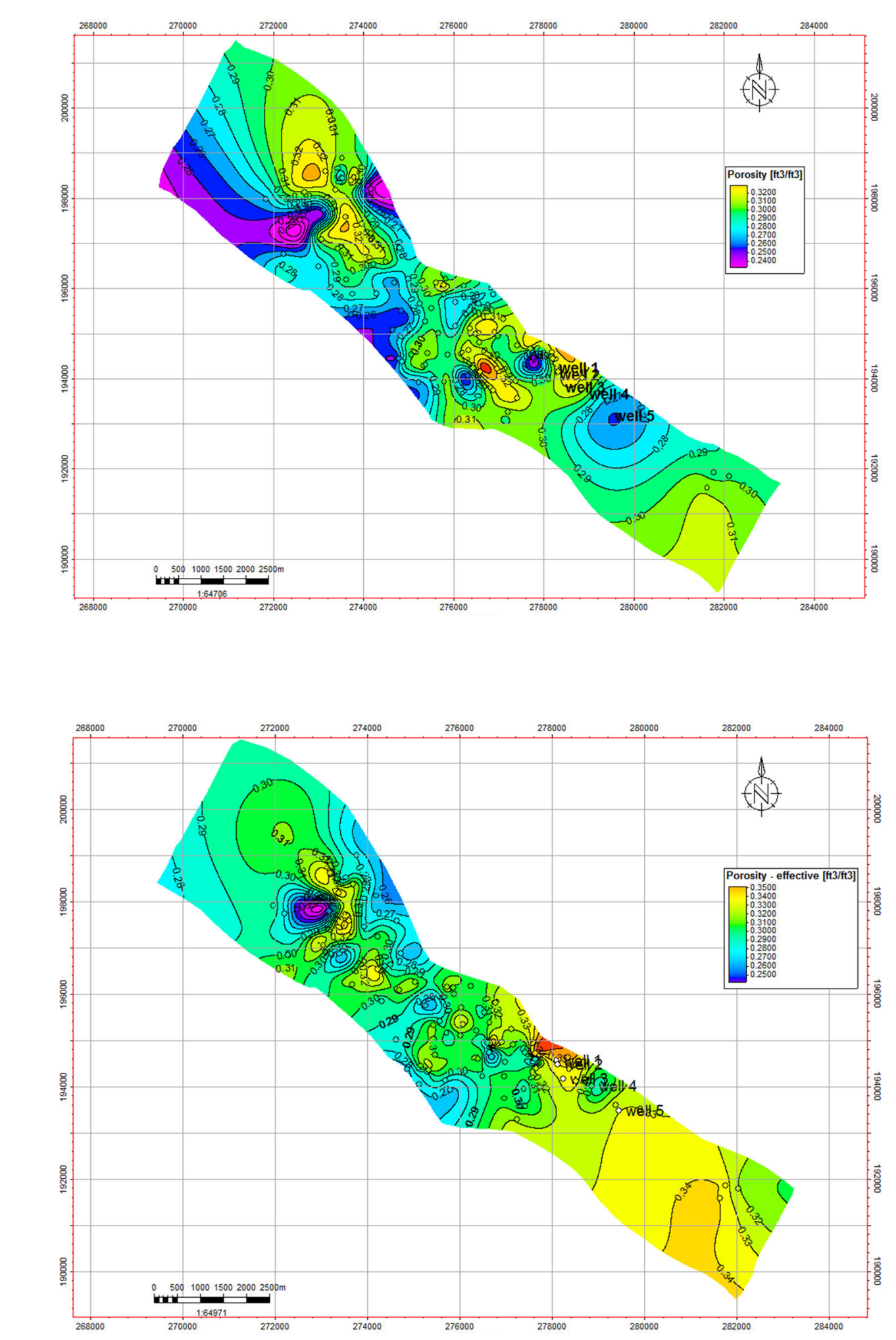

Fig. 15 Porosity map of sand E40 production and injection wells alike, has to be carefully planned and guided by information resulting from multidimensional and multi-approach study of the field as can be derived by integrating well log, seismic volume, core data, well test and production history data for the purpose of characterizing the field. 
Fig. 16 Water saturation map of sand $\mathrm{H} 10$

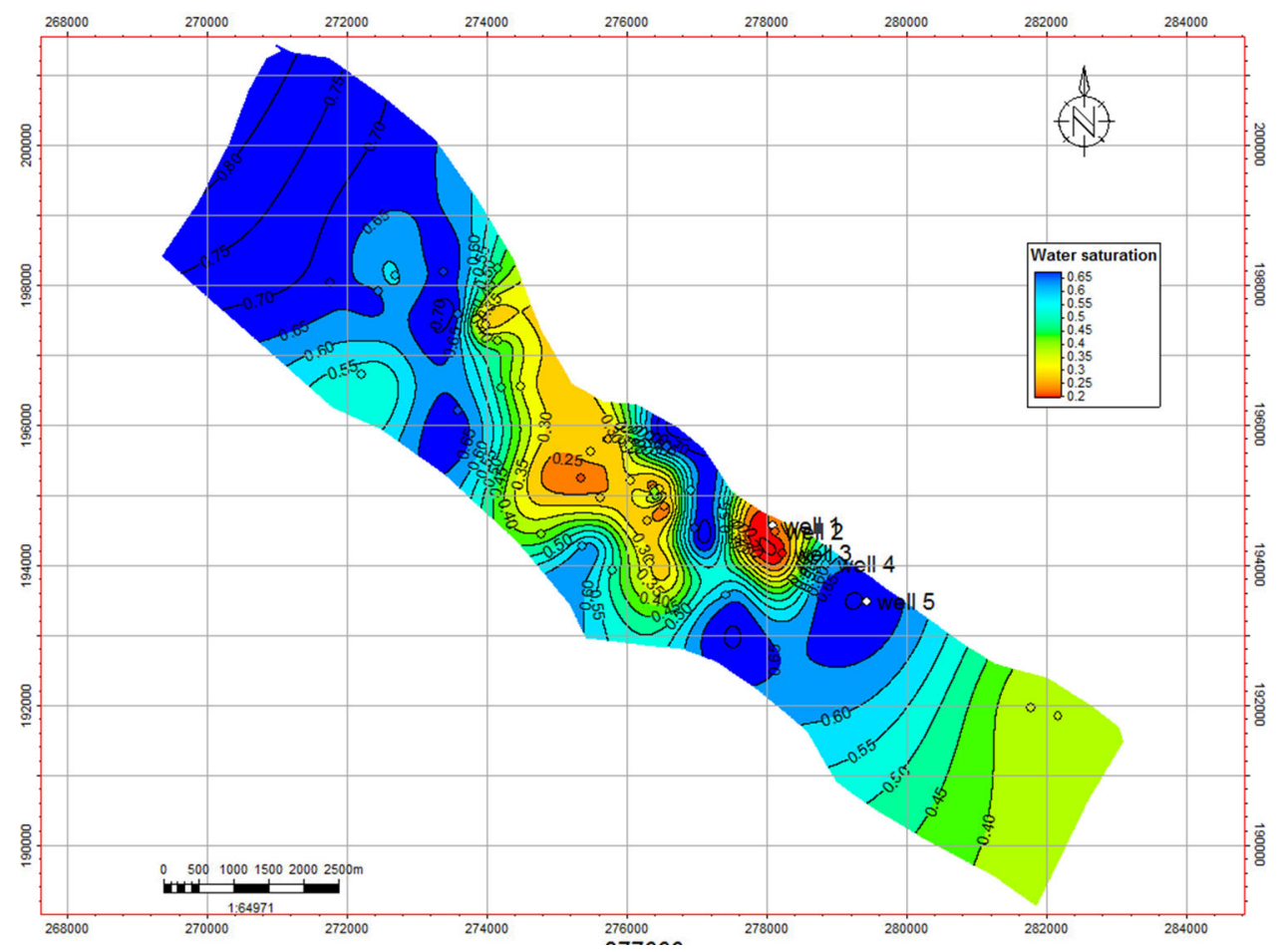

Fig. 17 Water saturation map of sand G20

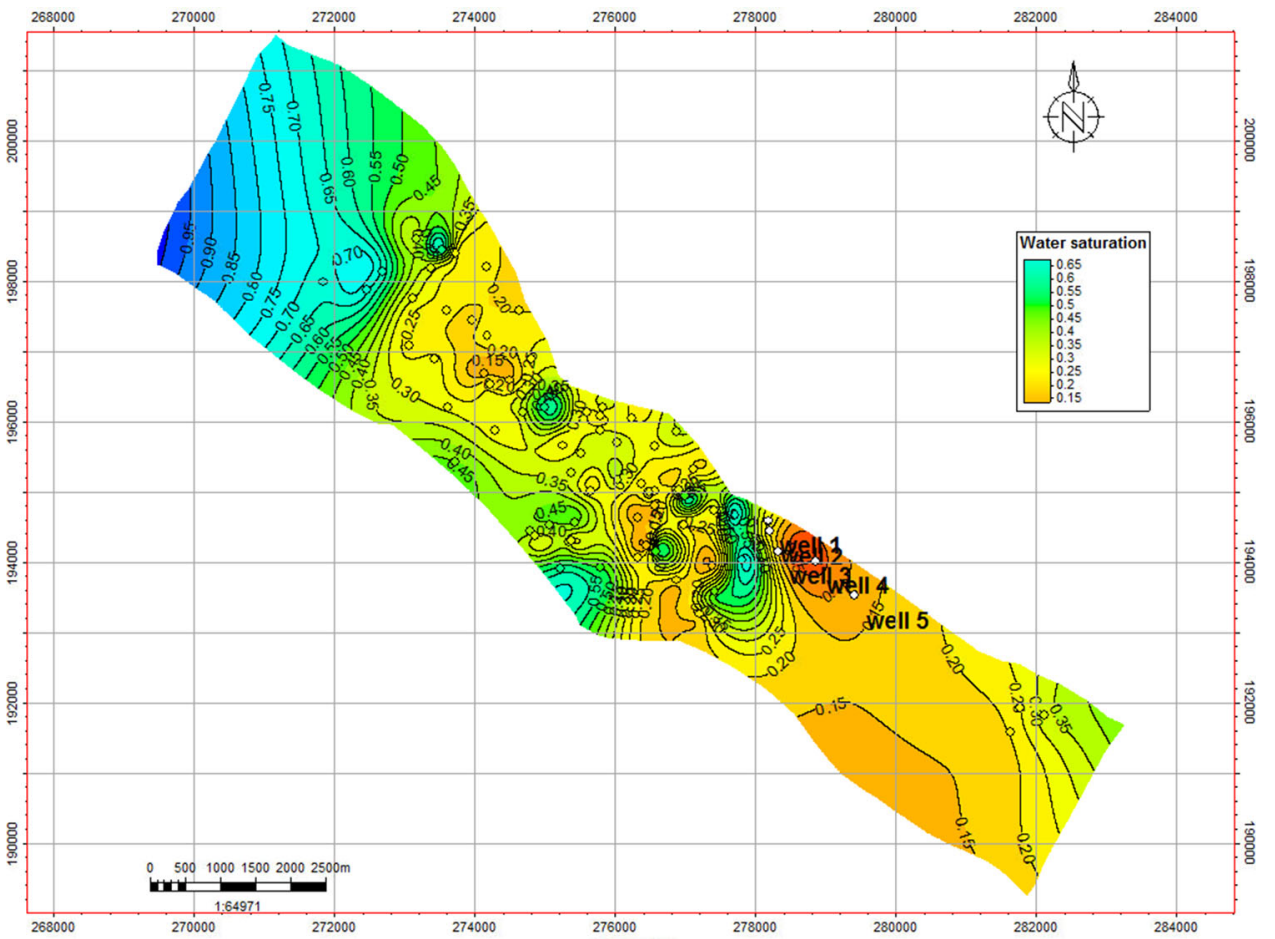

\section{Conclusion}

The integration of several subsurface information to evaluate reservoir qualities of Eni field, offshore Niger Delta in southern Nigeria has proved successful in identifying the likely reasons for production challenges presented as decrease in oil production with increasing water output. This study has analysed and integrated well logs, 3D seismic volume, core data, PVT and production data to generate information that would assist better 
Fig. 18 Water saturation map of sand E40

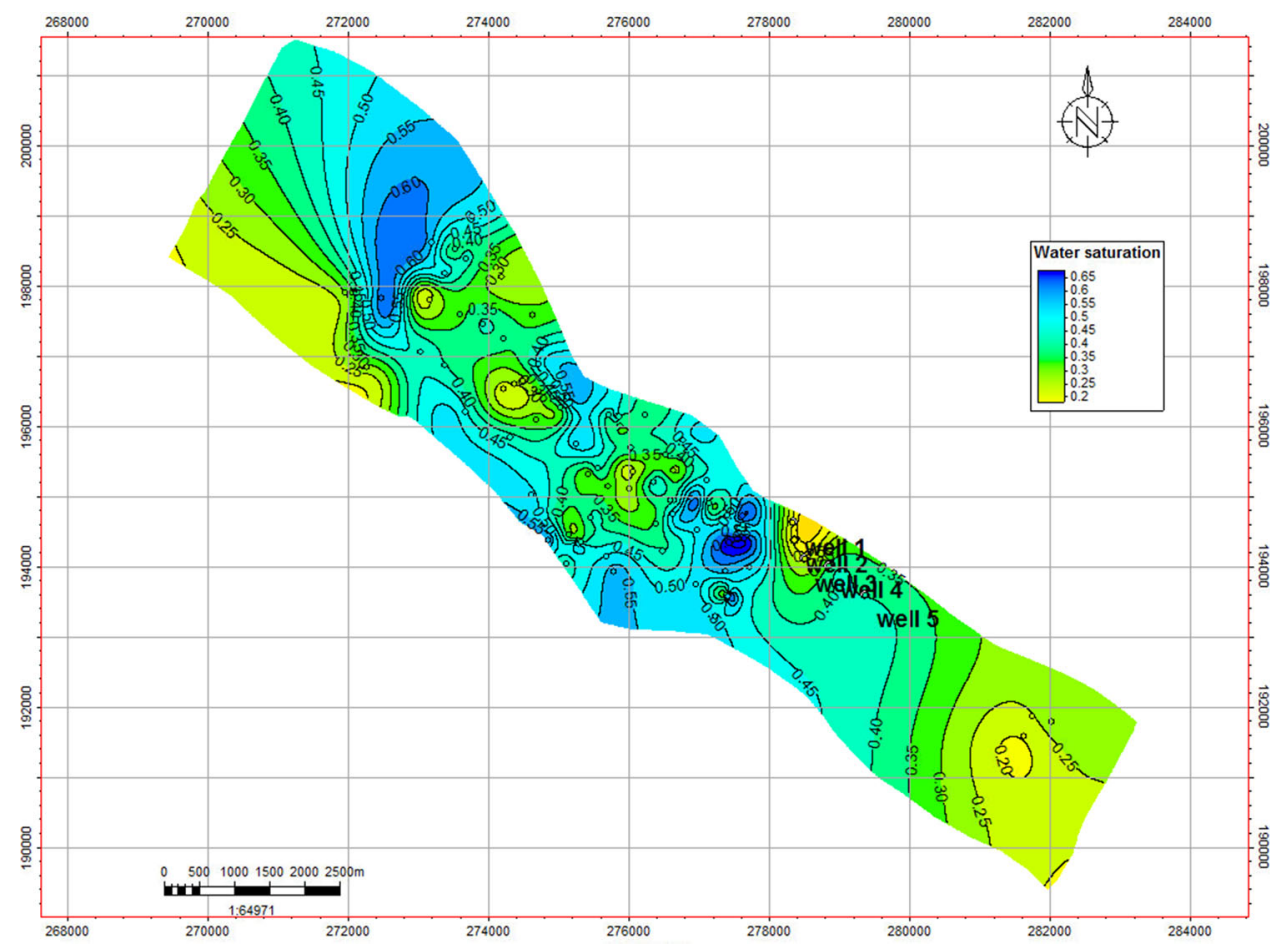

Table 2 Summary of estimated hydrocarbon volumes for reservoir sands H10, G20 and E40 using Probabilistic volume estimation approach

\begin{tabular}{|c|c|c|c|c|c|c|}
\hline & STOOIP (MMSTB) & Porosity & NTG & $S_{\mathrm{W}}$ & OOWC (TVDSS) & OGOC (TVDSS) \\
\hline \multicolumn{7}{|l|}{ H10 } \\
\hline P90 & 10.91 & 0.278 & 0.91 & 0.33 & -6132 & -5991 \\
\hline P50 & 11.69 & 0.299 & 0.93 & 0.260 & -6130 & -5989 \\
\hline P00 & 13.97 & 0.330 & 0.96 & 0.195 & -6128 & -5987 \\
\hline \multicolumn{7}{|l|}{ G20 } \\
\hline P90 & 2.92 & 0.32 & 0.92 & 0.24 & -5792 & -5763 \\
\hline P50 & 3.18 & 0.33 & 0.93 & 0.20 & -5790 & -5761 \\
\hline P10 & 3.63 & 0.35 & 0.95 & 0.16 & -5788 & -5759 \\
\hline \multicolumn{7}{|l|}{ E40 } \\
\hline P90 & 39.5 & 0.31 & 0.83 & 0.4 & -5430 & -5185 \\
\hline P50 & 41.7 & 0.33 & 0.9 & 0.31 & -5428 & -5184 \\
\hline P10 & 49.7 & 0.35 & 0.96 & 0.19 & -5426 & -5182 \\
\hline
\end{tabular}

Table 3 Estimated hydrocarbon volumes derived using deterministic approach from log-and core-derived reservoir parameters for sands H10, G20 and E40

\begin{tabular}{|c|c|c|c|c|c|c|c|c|}
\hline Parameters & & H10 & G20 & $\mathrm{E} 40$ & & H10 & G20 & E40 \\
\hline Porosity & Scenario 1 & 0.283 & 0.32 & 0.24 & Scenario 2 & 0.295 & 0.337 & 0.33 \\
\hline $\mathrm{S}_{\mathrm{W}}$ & & 0.127 & 0.20 & 0.13 & & 0.346 & 0.202 & 0.273 \\
\hline NTG & & 0.91 & 0.92 & 0.88 & & 0.91 & 0.93 & 0.91 \\
\hline OGOC (TVDSS) & & -5989 & -5761 & -5184 & & -5989 & -5761 & -5184 \\
\hline OOWC (TVDSS) & & -6130 & -5790 & -5428 & & -6130 & -5790 & -5428 \\
\hline Bulk volume $\left(10^{6} \mathrm{FT}^{3}\right)$ & & 464 & 214 & 1556 & & 464 & 214 & 1556 \\
\hline Net volume $\left(10^{6} \mathrm{FT}^{3}\right)$ & & 423 & 197 & 1370 & & 423 & 199 & 1413 \\
\hline Pore volume $\left(10^{6} \mathrm{FT}^{3}\right)$ & & 21 & 11 & 59 & & 22 & 12 & 83 \\
\hline $\mathrm{HCPV}_{\mathrm{OIL}}$ & & 18 & 4 & 49 & & 14 & 4 & 58 \\
\hline STOOIP (MMSTB) & & 13.39 & 3.03 & 40.12 & & 10.52 & 3.21 & 47.6 \\
\hline
\end{tabular}


management of the delineated reservoir compartments that make up the Eni field. The distribution of some reservoir properties as presented by the reservoir property maps could also guide the placement of both production and injection wells for optimum recovery.

Acknowledgements The authors gratefully acknowledge the support of Chevron Nigeria Limited for providing data for the study, provision of soft and hardware framework as well as permission to publish this work. Miss Fakehinde Abimbola and Mr Akin Idowu are also appreciated for their immense contributions.

Open Access This article is distributed under the terms of the Creative Commons Attribution 4.0 International License (http:// creativecommons.org/licenses/by/4.0/), which permits unrestricted use, distribution, and reproduction in any medium, provided you give appropriate credit to the original author(s) and the source, provide a link to the Creative Commons license, and indicate if changes were made.

\section{References}

Amigun JO, Bakare NO (2013) Reservoir evaluation of "Danna" field Niger Delta using petrophysical analysis and 3-D seismic interpretation. Pet Coal 2(55):119-127

Avbovbo AA (1978) Tertiary Lithostratigraphy of Niger Delta. Am Asso Petrol Geol Bull 62:295-300

Bailey WR, Manzocchi T et al (2002) The effect of faults on the 3D connectivity of reservoir bodies: a case study from the East Pennine Coalfield, UK. Pet Geosci 8(3):263-277

Behrenbruch P, Turner G, Backhouse AR (1985) Probabilistic hydrocarbon reserves estimation: a novel Monte Carlo approach. In: Paper SPE 13982 presented at offshore Europe 10-13 September, Aberdeen, Scotland

Brown AR (1986) Interpretation of three-dimensional seismic data. AAPG Mem 42:194

Cohen HA, McClay K (1996) Sedimentation and Shale tectonics of the north-western Niger Delta front. Mar Pet Geol 13:313-328

Cook G, Chawathe A, Larue D, Legarre H, Ajayi E (1999) Incorporating sequence stratigraphy in reservoir. An integrated study of the Meren E-01/MR05 sands in the niger delta. Houston (Texas). In: Paper SPE 51892 presented at the SPE reservoir simulation symposium, pp 14-17

Dalrymple RW, Choi K (2007) Morphologic and facies trends through the fluvial-marine transition in tide-dominated depositional systems: a schematic framework for environmental and sequencestratigraphic interpretation. Earth Sci Rev 81(3-4):135-174

Demirmen F (2007) Reserves estimation: the challenge for the industry. J Pet Technol 59(05):80-89

Doust HE, Omatsola EM (1990) Niger Delt. In: Edwards JD, Santagrossi PA (eds) Divergent/Passive Basins. AAPG Bull Mem 45:201-238

Ejedawe JE, Coker SJL, Lambert-Aikhionbare DO, Alofe KB, Adoh FO (1984) Evolution of oil generating window and gas occurrence in tertiary Niger Delta Basin. AAPG Bull 68:1744-1751

Evamy BD, Haremboure J, Kamerling P, Knaap WA, Molloy FA, Rowlands PH (1978) Hydrocarbon habitat of Tertiary Niger Delta. Am Asso Petrol Geol Bull 62:1-39

Farshi M (2008) Improving genetic algorithms for optimum well placement, master's report, Department of Energy Resources Engineering, Stanford University, California
Gay SP (1999) The strike-slip, compressional thrust-fold nature of the Nemaha system in eastern Kansas and Oklahoma. In: Merriam D (ed) Transactions of the 1999 AAPG mid-continent section meeting, Wichita

Guyaguler B (2002) Optimization of well placement and assessment of uncertainty, Ph.D. dissertation, Department of Energy Resources Engineering, Stanford University, California

Haldorsen HH, Damsleth E (1993) Challenges in reservoir characterization. Geohorizons 77(4):541-551

Herrera RH, Van der Baan M (2012) Automated Seismic-to-well Ties? In: 74th EAGE conference and Exhibition, p 1031

Jackson MD, Yoshida S, Muggeridge AH (2005) Three-dimensional reservoir characterization and flow simulation of heterolithic tidal sandstones. AAPG Bulletin 89(4):507-528

Jahns HO (1966) A rapid method for obtaining a two-dimensional reservoir description from well pressure response data. SPE J 6(4):315-327

Johnston D (2004) Reservoir characterization improves stimulation, completion practices. Oil Gas J 102(4):60-63

Journel AG (1995) Geology and reservoir geology. Stochastic modeling and geostatistics. In: Yarus JM, Chambers RL (eds) AAPG Computer Applications in Geology. 3:19-20. Tulsa, Oklahoma

Knox GJ, Omatsola EM (1989) Development of the Cenozoic Niger delta in terms of the "Escalator Regression" model and impact on hydrocarbon distribution. In: Proceedings of the KNGMG symposium on coastal lowlands, geology and geotechnology, 1987. Kluwer, Dordrecht. pp 181-202

Kogbe CA (1989) The cretaceous paleocene sediments of southern Nigeria. In: Kogbe CA (ed) Geology of Nigeria. Rock View Ltd, Jos, pp 320-325

Lehner P, De Ruiter PAC (1977) Structural history of Atlantic margin of Africa. Am Asso Petrol Geol Bull 61:961-981

Marsden D (1989) I. Layer cake depth conversion. Geophys Lead Edge 8:10-14

Merki P (1972) Structural geology of the Cenozoic Niger Delta. In: Dessauvagie FFJ, Whiteman AJ (eds) African geology. University of Ibadan Press, Ibadan, pp 636-646

Norrena KP, Deutsch CV (2002) Automatic determination of well placement subject to geostatistical and economic constraints. In: Proceedings of the 2002 SPE international thermal operations and heavy oil symposium and international horizontal well technology conference, Calgary, Canada, SPE 78996

Omoboriowo AO, Chiadikobi KC, Chiaghanam OI (2012) Depositional environment and petrophysical characteristics of "LEPA" Reservoir, Amma Field, Eastern Niger Delta. Nigeria Int J Pure Appl Sci Technol 10(2):38-61

Phillips C (1996) Enhanced thermal recovery and reservoir characterization. AAPG Pacific section-old oil fields and new life. A visit to the giants of the Los Angeles basin. p 65-82

Poston SW, Berry P, Molokwu FW (1981) Meren field: the geology and reservoir characteristics of a Nigerian Offshore field. In: Paper SPE 10344 presented at the SPE annual technical conference and exhibition, San Antonio

Refae AT, Khalil S, Vincent B (2008) Increasing bandwidth for reservoir characterization with single-sensor seismic data: a case study from Libya's challenging Lehib field. Pet Afr 26(2):41-44

Reijers TJA (1996) Sedimentary geology, sequence stratigraphy, three case studies, a field guide. SPDC Reprographic Services Warri, Nigeria

Reijers TJA (2011) Stratigraphy and sedimentology of the Niger Delta. Geologos 17(3):133-162

Rider MH (1986) Geological interpretation of well logs. Wiley, New York, p 175

Samimi AK, Karimi G (2014) Sensitivity and uncertainty analysis of original oil in place in carbonate reservoir modeling, a case study. Pet Coal 56(3):332-338 
Schmidt V, McDonald DA (1980) Secondary reservoir porosity in the course of sandstone diagenesis. AAPG Cont Educ Course Note Ser No 12:125

Smalley PC, Muggeridge AH (2010) Reservoir compartmentalization: get it before it gets you. In: Jolley SJ, Fisher QJ, Ainsworth RB, Vrolijk PJ, Delisle SD (eds) Reservoir compartmentalization, vol 347. Geological Society (London) Special Publication, London, pp 25-42

Snedden JW (1987) Validity of the use of the spontaneous potential curve shape in the interpretation of sandstone depositional environments. In: White BR, Kier R (eds) Transactions of the 34th annual meeting of the Gulf Coast Association of Geological Societies and 31st annual meeting of the Gulf Coast Section of SEPM. 34:255-263

Stacher P (1995) Present understanding of the Niger Delta hydrocarbon habitat. In: Oti MN, Postma G (eds) Geology of deltas. A. A. Balkema, Rotterdam, pp 257-267
Sweet ML, Sumpter LT (2007) Genesis field, Gulf of Mexico: recognizing reservoir compartments on geologic and production time scales in deep-water reservoirs. AAPG Bull 91(12):1701-1729. https://doi.org/10.1306/07190707011

Thakur GD, Haulenbeek RB, Jain A, Koza WP, Jurak SD, Poston SW (1982) Engineering studies of G-1, G-2, and G-3 reservoirs, Meren Field, Nigeria, paper SPE 10362. 34(04)

TuttleMLW, Charpentier RR, Brownfield ME (1999) The Niger Delta basin petroleum system: Niger Delta Province, Nigeria, Cameroon, and Equatorial Guinea, Africa; open-file report 99-50-H, United States Geological Survey World Energy Report, 4

\section{Publisher's Note}

Springer Nature remains neutral with regard to jurisdictional claims in published maps and institutional affiliations. 